\title{
Bank Lending and Business Cycles: South African Evidence
}

\author{
Oludele Akinloye Akinboade* and Daniel Makina**
}

\begin{abstract}
The paper provides empirical analysis on the linkage between the behavior of bank lending and business cycles in South Africa. Consistent with theory, overall evidence suggesting pro-cyclicality of bank lending is uncovered both at macro and micro levels. At macro level, bank lending and lending rates have moved in tandem with business cycles. Real borrowing by government was counter-cyclical to business cycles as would be expected if the role of government was to fine-tune the economy during booms and recessions. At micro level, bank lending to households and firms was generally pro-cyclical. Even the growth of provisioning by banks has been largely pro-cyclical to business cycles, though exceptions were recorded. First, new mortgage lending exhibited counter-cyclical behavior before 1993. We attributed this behavior to the political and economic climate prevailing then which created uncertainties that made ownership of property a good hedge against economic and political risks. Secondly, the growth of real credit for investment and of foreign trade finance does not appear to have been related to business cycles.
\end{abstract}

\section{Introduction}

This paper provides empirical analysis of bank lending and business cycle in Africa's most financially developed country, South Africa. This issue is important because there are variations in bank lending patterns which may coincide with particular business cycle episodes with attendant effect on economic growth of the country. Understanding this issue may lead us to a better appreciation of economic growth cycles especially in a developing country such as South Africa. Topics such as these are traditionally

\footnotetext{
*Department of Economics, University of South Africa, PO Box 392, UNISA 0003, Pretoria, South Africa; e-mail: akinboa@unisa.ac.za

** Department of Finance, Risk Management and Banking, University of South Africa, PO Box 392, UNISA 0003, Pretoria, South Africa; e-mail: makind@unisa.ac.za

(C) 2009 The Authors. Journal compilation (C) 2009 African Development Bank. Published by Blackwell Publishing Ltd, 476 9600 Garsington Road, Oxford OX4 2DQ, UK and 350 Main Street, Malden, MA 02148, USA.
} 
under-studied for reason of lack of data. As a matter of fact, very few African countries provide business cycle data. Identifying the episodes alone is fairly cumbersome and hence data are lacking for many African countries.

In this paper we contribute to the literature by seeking to establish linkage between business cycles and the flow of bank lending in South Africa. South Africa offers an ideal laboratory for study because of its turbulent history - both politically and economically. The country has gone through many structural changes since the 1970s, and unlike other African countries, it has a fairly developed banking sector that is comparable to those of developed countries. The rest of the paper is structured as follows. The next subsection presents the business cycle theoretical framework. Section 2 describes business cycle as well as banking cycle episodes in South Africa. Section 3 discusses the methodology and data used to establish linkages between banking lending and business cycles. Section 4 provides empirical results. Finally, Section 5 concludes.

\subsection{Theoretical Framework}

Business cycles are defined as recurring patterns of recession (economic decline) and recovery (economic growth). An economy recurrently experiences periods of expansion and contraction, and the length of these cycles is usually irregular. The recurring expansions and contractions of the national economy are usually measured by real gross domestic product. Though the government uses tools to fine-tune the economy, for instance, to maintain low unemployment and (through the South African Reserve Bank [SARB]) low inflation, economies repeatedly seem to pass through good and bad times. Typically, a complete cycle lasts from 3-5 years, but could last ten years or more and is usually divided into four phases: expansion, peak, contraction, and trough. ${ }^{1}$ Haberler (1958) has defined business cycles as the alternation of relatively prosperous and depressed times, together with all the concomitant changes in all parts of the economic system, which extends over the period of 3-12 years. Although Haberler refers to cycles of 3-12 years, this censoring rule does not accord with empirical evidence. Importantly, the business cycle refers to the total economic system or aggregate economic activity. Essentially, macroeconomic shocks are aggregated into business cycles. While the definition of a business cycle appears to be straightforward, there is a lot of controversy as to its nature, underlying cause and the length of time it lasts. Over the years, there have been numerous theories of why economic activity fluctuates so much.

Since Keynes' (1936) seminal work, researchers have grappled with the question as to whether banks change their lending standards systematically over the business cycle, and that if they do whether there is a discernible and 
economically important effect on aggregate fluctuations. Empirical research suggests that one major contributor to the boom and bust nature of the business cycle is the way that banks alter their lending standards over economic peaks and troughs (Farmer, 1985, 1988; Gorton and Kahn, 1993; Greenwald and Stiglitz, 1993; Smith, 1995; and Zarnowitz, 1985). Asea and Blomberg $(1997,1998)$ further report systematic patterns in lending standards, with banks tightening credit in recessions and easing it during expansions, arguing that lending cycles exacerbate business cycles. Notably, they observe that changes in lending standards that are usually relaxed during expansions do sow the seeds of future recessions because borrowers who are likely to default are selected in the process. In any case bank lending in general tends to be pro-cyclical, that is, it contracts during an economic slowdown and rises during an expansion.

A shift in the risk profile of banks over the business cycle can also be caused by changing incentives on the part of banks. Economic downturns may produce the conditions in which banks have incentives to lower their lending standards and, hence, increase their riskiness. Rajan (1994) argues that bank managers with short horizons will set credit policies that are driven by demand side conditions, which could amplify business cycle movements. Kiyotaki and Moore (1997), Asea and Blomberg (1998) observe that these risk incentives may cause lending cycles and associated swings in the riskiness of banks. Furthermore, Repullo (2004) and Schoors and Vander Vennet (2003) show that a gambling equilibrium may exist when the degree of asymmetric information increases, which is typically associated with recessions. However, they also show that this risky behavior is less likely to occur when capital adequacy rules are binding.

The pro-cyclical feature of bank lending to businesses is also partly driven by demand. Business cycle impacts on bank profitability through decreased demand for credit. When the economy goes into recession, the value of some firms' collateral or their net-worth-at-risk declines, enough to make them ineligible for the loan. The demand for net working capital falls, as employment and business investment decline. This weaker demand affects the quantity of bank loans to businesses and would be expected to persist into a recovery. At this time, it becomes harder to increase capital and reserves and to raise new capital. In this event, some firms can obtain loans at their banks at an elevated interest rate, but others are simply unable to borrow, with the net effect of curtailing business credit. During an economic expansion, the opposite occurs, as more businesses become eligible for loans under the banks' terms and conditions of lending. As Bernanke and Gertler (1989) and Berger and Udell (1992) argue, this scenario suggests not only that bank lending is pro-cyclical, but also that the availability of bank loans to fund the economic activities of businesses may exacerbate the magnitude of business cycles. 
Theories of imperfect capital markets argue that asymmetric information and agency costs are typically high during business cycle troughs and low during booms (Bernanke and Gertler, 1989; Kiyotaki and Moore, 1997). In an economic downturn, it becomes more difficult for banks to assess the creditworthiness of corporate borrowers. Since adverse economic conditions have a negative impact on the cash flows of borrowers, banks may suffer losses because some of their outstanding loans default. At the same time, the assessment of new loan applicants becomes more subject to type I errors because the net present value of new corporate investment becomes more uncertain. Moreover the net worth of companies and the value of their collateral assets decrease. Since the value of collateral is likely to be pro-cyclical, asymmetric information will be relatively high in business cycle downturns and relatively low in booms. This implies that bank intermediation becomes riskier during downturns through a reduction in the value of collateral assets attached to outstanding loans and an increase in the degree of asymmetric information. In theory, banks can compensate for a riskier environment by tightening their lending standards - by charging higher interest rates on their loans, by demanding more collateral, and by simply refusing to lend to marginal customers (Lown and Morgan, 2001).

Faced with adverse business cycle conditions, banks may elect to ration credit. This happened in a number of periods, both in the US and in Europe. Peek and Rosengren (1995) argue that the recession of 1990-1 in New England was reinforced by the reluctance of banks to lend. Also in the most recent business cycle downturn (2000-3), banks have been accused of being excessively restrictive, both in the US and in Europe (The Economist, 2002). Credit rationing may also result from banks' weak capital or weak loan portfolio positions, and such conditions may coincide with an economic downturn. For example, empirical evidence suggests that credit rationing played a significant role in limiting the expansion of bank loans to businesses during the 1991-2 recession in the USA, due to a combination of new riskadjusted capital standards, tighter regulatory oversight, and changes in bank lending practices, as banks attempted to reduce the riskiness of their overall asset portfolios (Berger and Udell, 1994, 2002).

\section{Business Cycle Episodes in South Africa}

South Africa is currently in its 14th business cycle since the Second World War (SARB, 2007). Since the end of the Second World War, economic upswings have averaged 25.6 months in length while economic downturns have averaged 20.4 months. South Africa mostly experienced economic upswings during 55.7 percent of the period, the rest being economic downswings. Table 1 presents business cycle categorization by phase by 


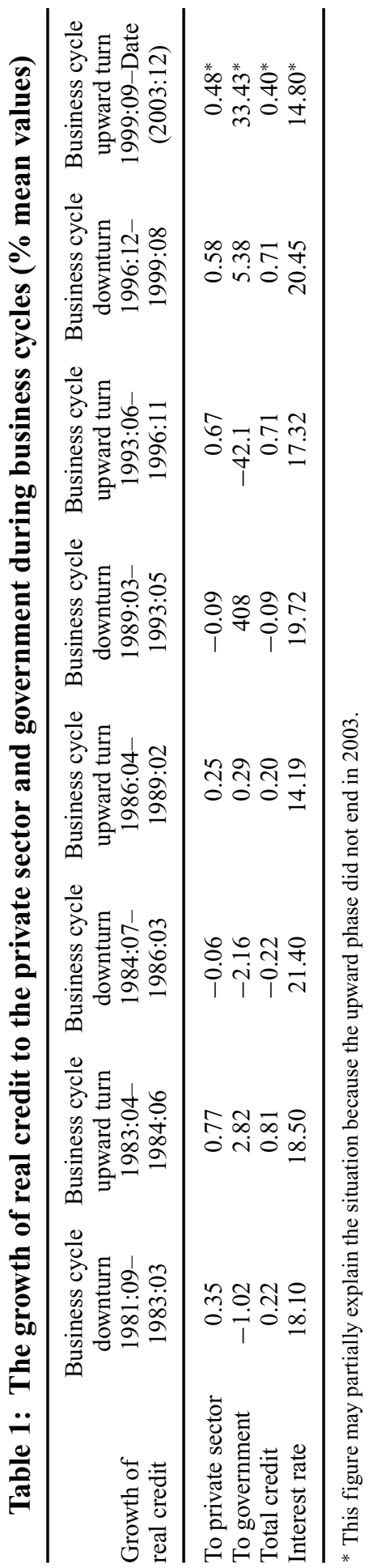

(C) 2009 The Authors. Journal compilation (C) 2009 African Development Bank 
the SARB. Laubscher (2002) reports that analysts have identified major structural business cycle periods. During the first structural period from 1946 to 1973, there was an upward secular growth pattern. During this time, South Africa witnessed nine complete business cycles averaging 36.1 months in length. Upswing phases lasted an average 22.1 months while downswing phases lasted 13.4 months. During this period, the economy did not experience negative real GDP growth.

However, this changed since the mid-1970s. During 1973 to 1993, no less than 6 calendar years of negative growth was registered as growth trends turned downwards. The downswing phases of the business cycle lengthen over this period, and the amplitude of the fluctuations increased. This implied greater economic instability.

The International Monetary Fund (April 2002, cited by Laubscher, 2002) attributes this to three developments signifying structural change since 1973, that is, the new international monetary regime of floating exchange rates, lower real GDP growth rates, reflecting a decline in productivity growth in the major industrial countries in the post-Second World War period; and the emergence of level recessions in these countries, partly due to the first oil shocks. Though South Africa only moved to a system of floating exchange rates in 1979, the oil shocks of 1973/4 and the conflict in Angola following that country's independence had major implications for the domestic economy. There were also large fluctuations in the gold price, domestic political unrest and instability (e.g. June 1976, July 1985 and June 1986), protracted agricultural droughts in the 1980s (and early 1990s) and the international debt moratorium and the collapse of the rand in 1985.

At this time, both monetary and fiscal policies in South Africa were often subject to non-economic factors and may have contributed to economic fluctuations. The country's fiscal policy tended to be expansive (due to the demands of defense spending and the reigning view at the time of Keynesian demand management to stimulate economic growth) while such fiscal expansion was often accommodated by monetary policy, which contributed to excessive growth in bank credit utilization and real domestic expenditure and imports (Laubscher, 2002).

In the early 1990s, South Africa's business cycle was characterized by a protracted economic downturn of 51 months in length. This was followed by an upturn that commenced ahead of the historical April 1994 general elections. It lasted a total of 42 months. The recession, which followed was equally long and lasted 33 months.

There are similarities between the business cycle phases of the second half of the 1970s and those since 1993. During the recessions in both periods, the growth of real GDP remained positive. Also, in both periods the upswing phases were considerably longer when compared to the 1980s. These are highlighted in the table in the Appendix. 
Figure 1: Stages of a banking cycle
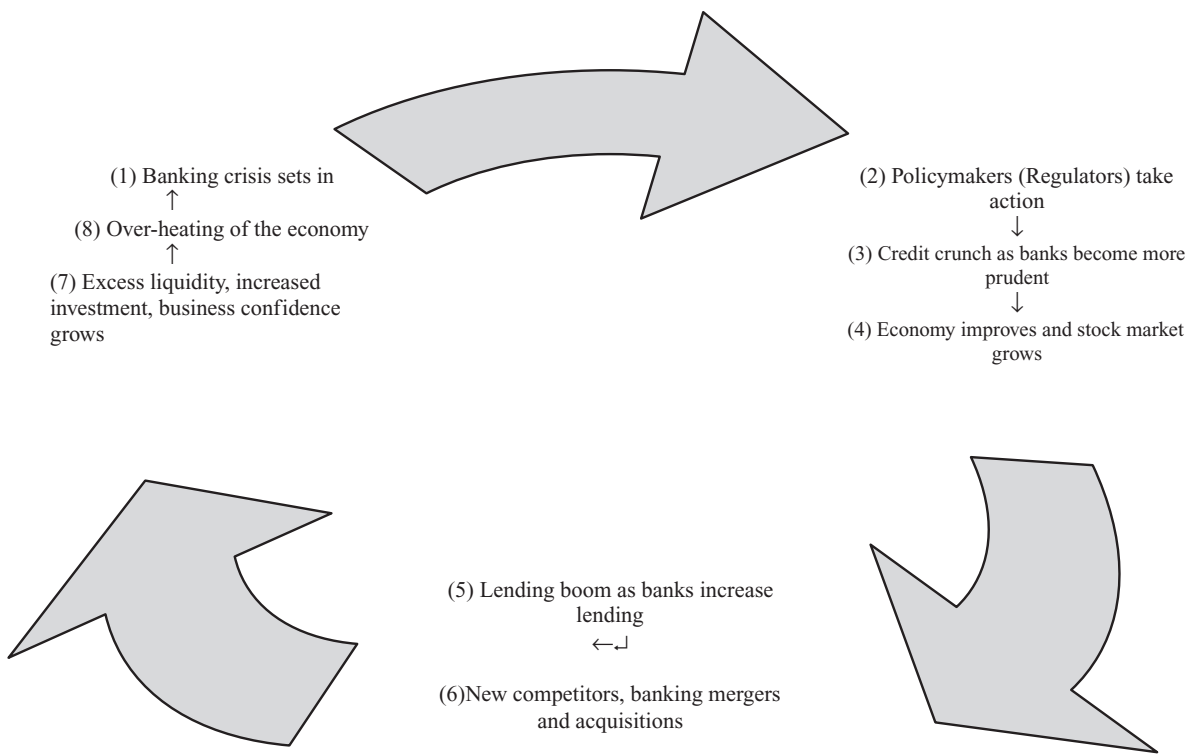

(5) Lending boom as banks increase lending $\leftarrow \downarrow$

(6)New competitors, banking mergers and acquisitions

Source: Derived from SARB (several years).

\subsection{Banking Cycle Episodes in South Africa}

The South African banking industry has undergone structural changes attributable to recent financial liberalization initiatives. The South African Reserve Bank outlines eight broad stages of a cycle through which banking activities and banks progress. The stages of a typical banking cycle are highlighted in Figure 1. South Africa experienced stage 1, a banking crisis, during the period from late 1999 to 2002. Many regulatory actions were taken and implemented during stage 2 , and normality returned to the banking sector. During stage 3, many bankers became more prudent and instituted actions such as down or rightsizing of businesses, curtailment and critical evaluation of cost structures, disposal of non-core and non-performing assets and investments, and an overhaul of risk-management practices and structures, among other things. Recently, there has been evidence of the fourth stage, namely that of the economy and stock markets taking off. From 2004 onward we have witnessed increased loan growth which is characteristic of stage 5 . There were also signs of stages 6 and 7 -new competitors and excess liquidity and investment optimism - as evidenced by some international players expressing an interest in acquiring a stake in South African banks and reports of a build-up of excess cash in some banks. What is of interest to regulators is whether the cycle will be completed to 
reach stage 8 , at which time the overheating of the economy becomes of concern to regulators (SARB, 2005a).

This recent and ongoing structural change in the industry may significantly alter the role of banks in the transmission of monetary policy. A change in banks' overall willingness or ability to grant loans may lead to a predominantly cyclical lending practice. Such type of lending, however, may not be in harmony with the financing needs of the real economy and may even reinforce the cyclical nature of the economy, leading to a procyclical lending practice. Hence, a major concern of policymakers is to understand the ways that changes in the banking industry, such as those depicted in Figure 1 and in the patterns of firm finance may alter their ability to control, or even predict business cycle fluctuations. From the point of view of macroeconomic stability, it is important to prevent the two extreme cases of pro-cyclicality, 'credit crunch' and 'lending boom'.

SARB has determined business cycle episodes for the country since 1945 (see Smit and Van der Walt, 1970, 1973; Van der Walt and Pretorius, 1995 and other publications in the South African Reserve Bank's Quarterly Bulletins). The peaks and troughs in the economy have generally been regarded as the reference turning points in the business cycle. The methods used by the SARB to determine the turning points of the business cycle are documented by Pretorius et al. (1999) and Venter and Pretorius (2001). First, they involve the computation of the composite leading and coincident business cycle indicators. Secondly, they involve the computation of a comprehensive composite index, known as the current diffusion index. Thirdly, a historical diffusion index defined as a measure of dispersion of the changes in a number of time series during any particular period is computed. Finally, important economic events and developments occurring near a possible turning point are taken into account in the process of determining the exact date of the turning point.

\section{Data and Methodology}

\subsection{Data}

All the data series have been sourced from the database of the South African Reserve Bank (SARB, 2005b). For most of the series, disaggregated bank lending data are available only from 1980. Hence, our analysis of bank lending over the business cycle covers the 1980-2003 period. Disaggregated lending data analyzed comprised the following categories in money values: lending to the private sector, lending to government, total household lending, installment finance, lease finance, mortgage advances and other 
loans. Where data was available there were additional disaggregations within these categories that lent themselves for further analysis.

\subsection{Methodology}

A simple approach whereby descriptive statistics of lending volume (in values) during each business cycle episode were computed and interpreted for every lending category. The lending rates for each category during the various business cycle episodes were subjected to the same approach. The adopted approach is considered powerful enough to give indications of the behavior of bank lending during alternate business cycles of boom and bust. In any case the interpretation of descriptive data forms an important precursor for any further complex analysis in empirical studies.

\section{Empirical Results and Discussion}

\subsection{Ratio of Domestic Credit to GDP}

Figure 2 gives the ratios of total domestic credit to GDP, total credit to the private sector to GDP and total credit to government to GDP in South Africa over 1970-2002. The ratios have been fairly stable over time. A private/public sector split of domestic credit can give an indication of the role of the state in the financial and real sectors of the economy. Similarly, on the assets side, the ratio of domestic credit to GDP can give an indication of financial depth and the degree to which the formal banking sector plays a role in South Africa.

Figure 2: Ratio of domestic credit to GDP in South Africa

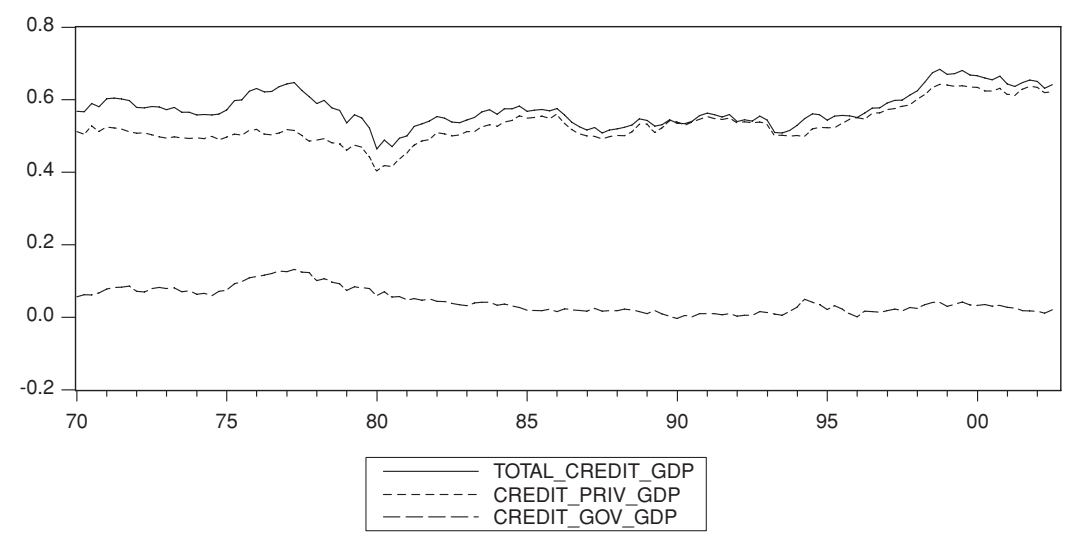


During the 1970-80 period, total domestic credit as a proportion of GDP was 59 percent. The amount that went to the private sector was 50 percent of GDP. State involvement (which attracted an average of 9 percent of total credit to GDP) was important in South Africa at this time, reflecting the risky investment climate in the country, the effect of sanctions and disinvestment, and the reluctance of banks to lend given the already large non-performing loans to public enterprises of the banking system. Between 1980 and 1993, total domestic credit declined a little to 54 percent of the GDP. The ratio of private sector credit to GDP was 51 percent. This reflects low government borrowing at this time. Since banking sector reforms accompanied economic liberalization, total credit in the economy has risen since 1994. Between 1994 and 2002, total domestic credit increased to 62 percent of GDP. This increase is accounted for by increased extension of credit to the private sector (59 percent of GDP) especially taking into consideration that fiscal deficit decreased significantly from about 6 percent of GDP to just over 2 percent around this time.

\subsection{Credit Tightening over the Business Cycle}

The effects of credit tightening which occurs during downturns can be shown in Figures $3 \mathrm{a}$ and $3 \mathrm{~b}$ with regard to both total credit and credit to the private sector. The growth rate of bank lending is quite volatile, but tends to dip when the economy enters into recession. Loan prices - proxied here by the lending rate - tend to rise as the economy enters into recession. From the two graphs this is evident for the downward phases: September 1981-March 1983; July 1984-March 1986; and March 1989-May 1993. These interest rate changes probably understate the price response by banks, as the spreads over lending rate charged to the riskiest borrowers can rise.

\subsection{The Growth of Real Credit to the Private Sector and Government during Business Cycle}

Business cycle theory suggests that during a downturn banks' loan supply curves will shift up and to the left (Bernanke et al., 1996). The corollary of this argument is that an upward turn would shift banks' loan supply curves to the right, increasing bank lending. Table 1 highlights evidence of this in the case of credit to the private sector and total credit in the economy of South Africa. Bank lending to the private sector grew on average by between 0.25 percent during the 1986-9 economic upturn and 0.77 percent during the 1983-4 upturn. Whereas during economic downturn, bank lending to the private sector either declined by 0.09 percent (during the 1989-93 downturn) 
Figure 3: (a) Bank lending and lending rate; (b) Bank lending to the private sector and lending rate

(a)

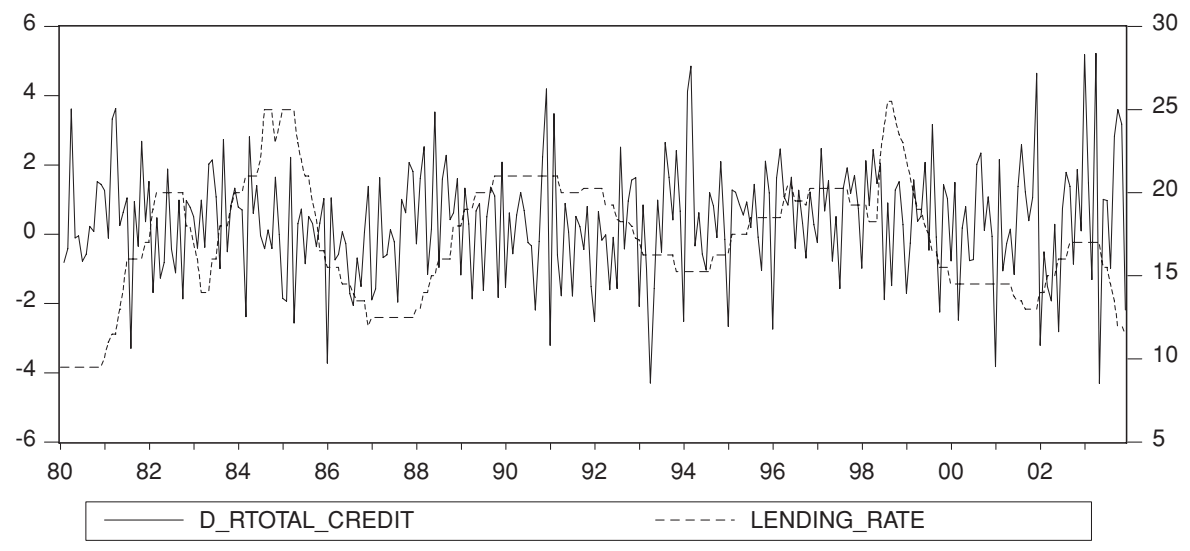

(b)

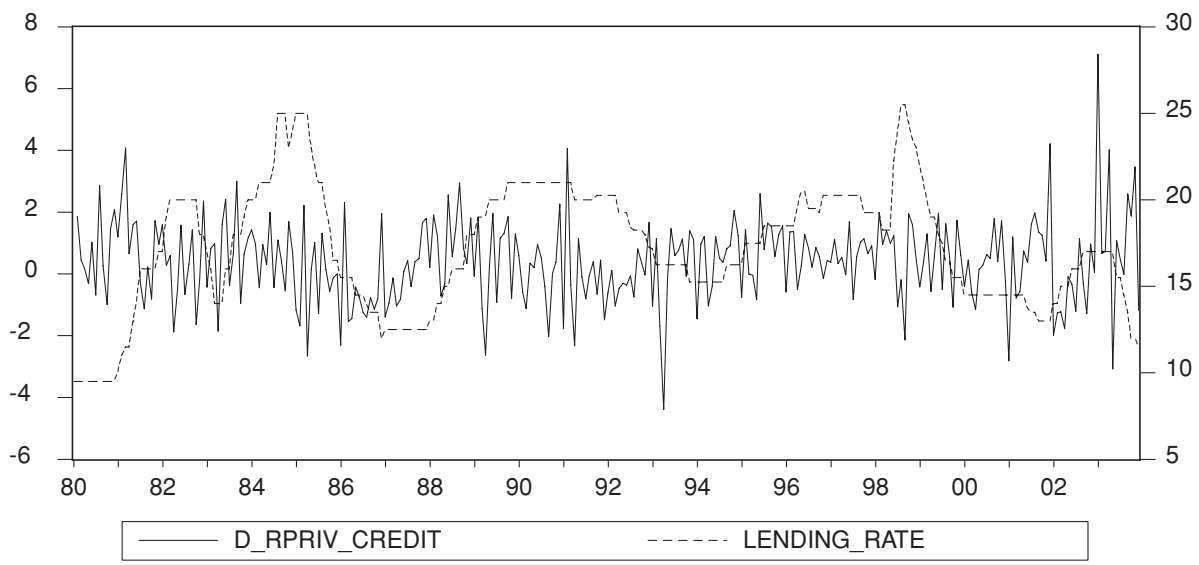

Source: SARB (several years).

or increased marginally by 0.35 percent as it occurred during the 1981-3 downturn.

The expectation is that government should pursue an expansionary macroeconomic policy (deficit funding) during a downturn to neutralize the adverse effects and a restrictive policy (less borrowing) during an upward turn to prevent the economy from overheating. Talvi and Vegh (2000) show that tax collection increases during a period of economic expansion and falls during recessions, and that government spending is countercyclical in G-7 countries. Though government spending is pro-cyclical for other 
industrialized countries, it is less so than tax revenues. However, in Latin American countries, tax collection is strongly pro-cyclical, but this comes together with extremely pro-cyclical government expenditure (Sturzenegger and Werneck, 2004). Some authors suggest that fiscal deficits tend to be more pro-cyclical in emerging markets. Gavin et al. (1996) suggest that procyclicality arises from limited access to capital markets during downturns, that prevents developing countries' governments from borrowing in bad times, thus forcing them to contract expenditures when it needs them most.

During the 1980s, South African government borrowing was pro-cyclical as policies responded to non-economic factors. This has, however, changed since the 1990s. At this time, real borrowing by government was countercyclical to business cycles as would be expected if the role of government was to fine-tune the economy over booms and recessions. During the 1990s, growth of real credit to government was counter-cyclical and increased during business cycle down turns. Table 2 also shows that lending rates have been largely pro-cyclical as expected, increasing during economic downturn and reducing during booms.

\subsection{Behavior of Bank Loans to Consumers}

While aggregate lending is pro-cyclical, when disaggregated it could be assumed some components may show some different patterns. Nonetheless, loans to consumers in Table 2 show a pro-cyclical pattern over the business cycles. Total credit to households, installment finance, lease finance, mortgage advances and other loans all generally declined or grew slowly during economic downward phases and increased during economic booms. This is expected as the lending rate, itself pro-cyclical, would determine the demand and supply of loans. Households are traditionally the main recipients of bank loans in the form of mortgage advances for residential buildings. An increasing portion of bank credit in the form of installment sale credit and leasing finance, which traditionally flowed to the corporate sector, has been going to households in recent years, to finance equipment, vehicle finance and house furnishing purchases.

Table 3 further disaggregates mortgage advances with a view to obtain more insight.

From 1981 to 1993 new mortgage lending appears counter-cyclical. It could have been affected by the political and economic climate prevailing before 1993 characterized by the imposition of economic sanctions against South Africa and disinvestments. In the uncertainties prevailing at the time, ownership of properties could have been a good hedge against economic and political risk. In response to three consecutive cycles of declining real stock prices starting in 1984, households shifted their assets into real estate. 


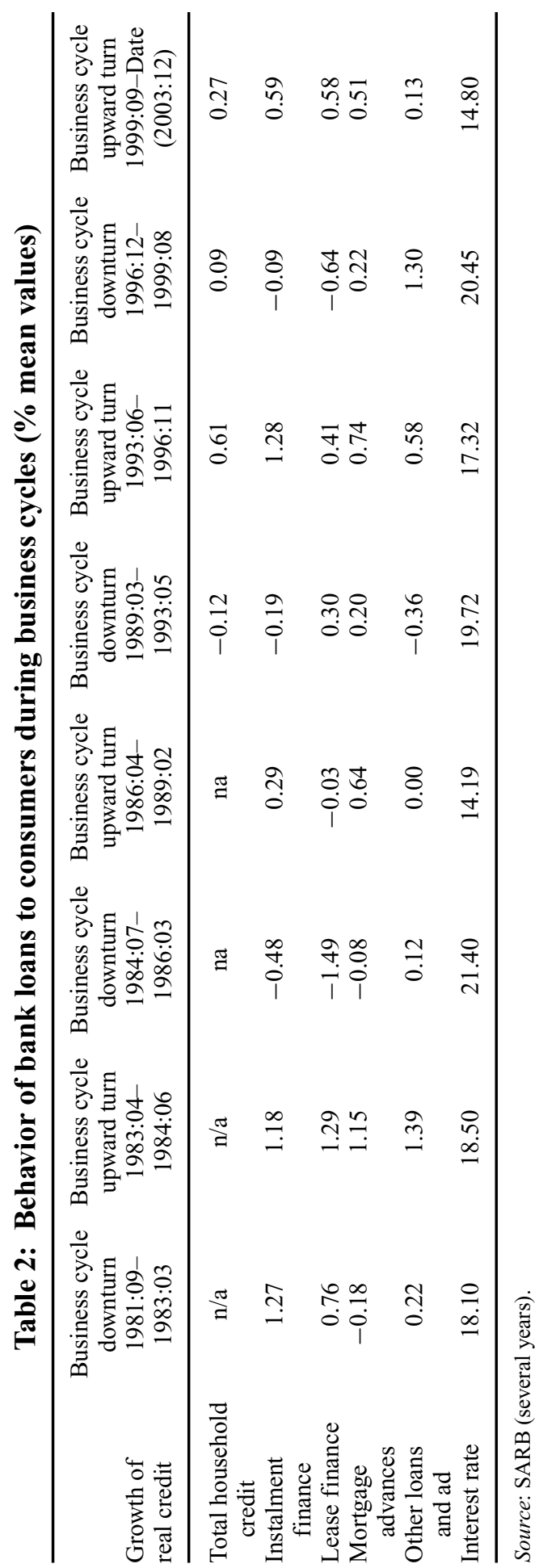

(C) 2009 The Authors. Journal compilation (C) 2009 African Development Bank 


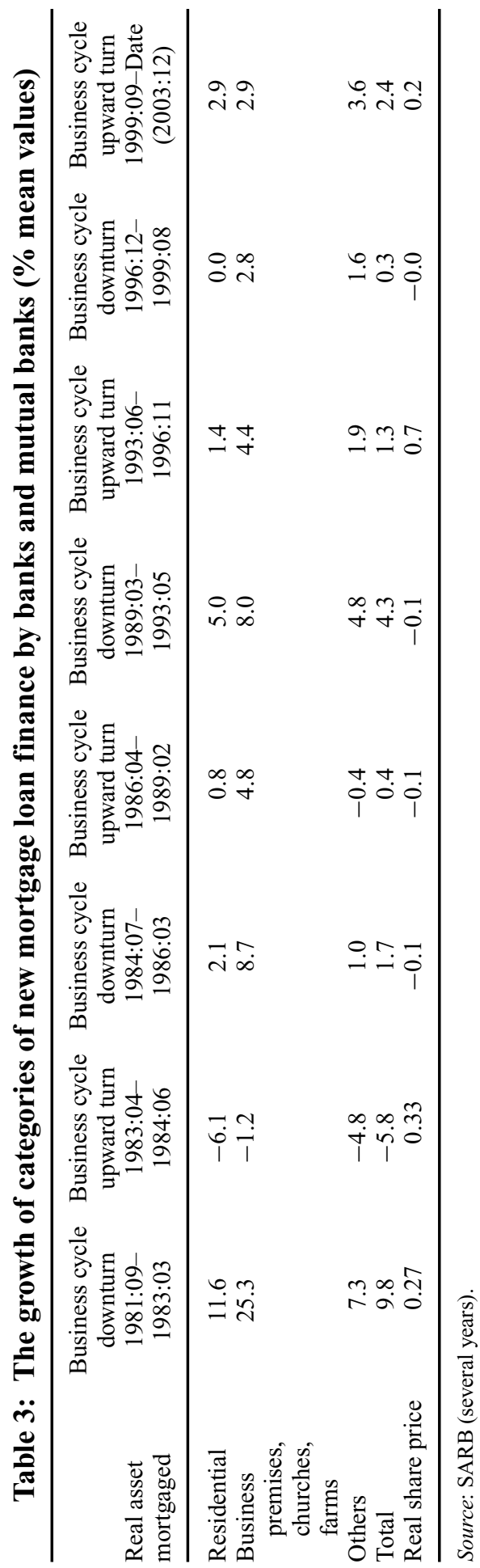

(C) 2009 The Authors. Journal compilation (C) 2009 African Development Bank 
However, the shift into new real estate purchases is more evident during business cycle slowdowns in comparison to upward turns. This portfolio rotation effect has contributed to the strength of the residential housing market in recent years. House price appreciation in recent years has been more than double real estate prices realized in 1994. From 1993, the entry into the market of individuals and households from previously disadvantaged communities resulted in a surge in mortgage demands, an appreciation of mortgage prices and a possible reversal in historical trends of mortgage demand-stock price relationship in South Africa. During this period, the upward business cycle is associated with increases in real share prices as well as in new mortgage finances.

During business cycle upturns, house prices are generally high, spurned by low mortgage rates. As such, in comparison to what obtained in a business cycle downward turn, the degree of mortgage loans affordability is low to new home buyers. This might explain why there is traditionally a reduction in the rate of growth of new mortgage lending during the upward phase of the business cycle. Bank lending for new residential buildings declined by as much as 6.1 percent during the economic boom of 1983-4 or grew slowly by 2.9 percent during the recent economic boom (1999 to date i.e., 2003:12). The same pattern can be deciphered in respect of mortgage lending for new business premises, churches and farms. On the other hand, during economic downturns, mortgage lending for new residential buildings, businesses, churches and farms have tended to grow significantly.

\subsection{Other Categories of Bank Credit to Firms}

Table 4 shows the behavior of other categories of lending during business cycles, namely investment finance, bills discounting, foreign trade finance and resale agreement loans. Evidently, growth of real credit for investment does not appear to have been related to business cycles. In fact it had been negative in years of economic sanctions prior to political liberalization. From 1989 the growth rate had been positive but still having no relationship to the business cycle. The growth of bills discounted (factoring of debts by banks) was counter-cyclical during the first four business cycles under consideration and became hardly related to the business cycle thereafter. Being countercyclical is expected of discounted bills because we would expect firms to seek more factoring of their loans during downturns when debtors struggle to pay than during upward turns. The growth of loans granted under resale agreements appears lower during economic downturns in comparison to subsequent economic booms. The growth of foreign trade finance, on the other hand, does not seem to be related to business cycles. 


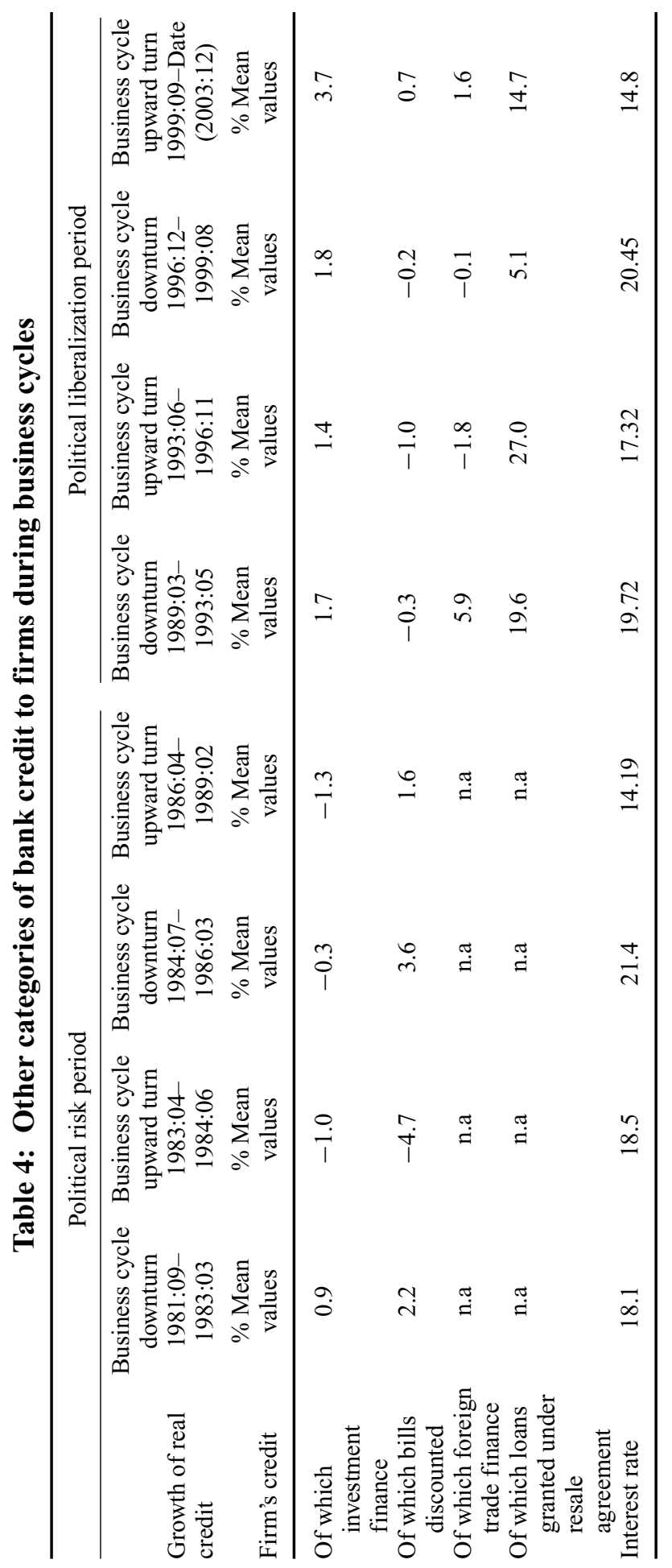

(C) 2009 The Authors. Journal compilation (C) 2009 African Development Bank 


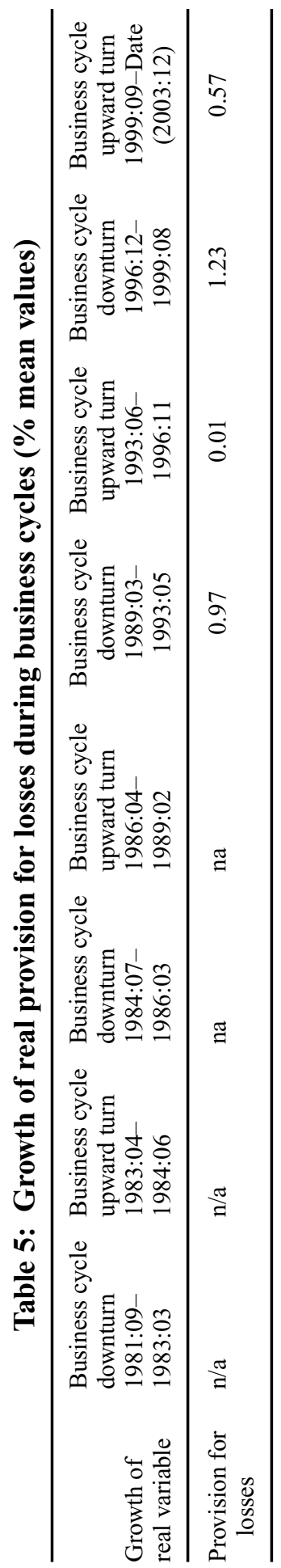

(C) 2009 The Authors. Journal compilation (C) 2009 African Development Bank 


\subsection{Banks' Provision for Losses during Business Cycle Phases}

While the primary response of banks to a slowing economy is to adjust credit standards on new loans, the main impact on banks of a slowing economy is impaired credit quality of existing loans. As Table 5 shows, the growth of provisioning by banks has been largely pro-cyclical to business cycles. The provisioning charge with respect to non-performing loans appears to grow less during business cycle upturns compared with episodes of downturns. This behavior accords with theory. We expect the default rate to be higher during the downward phase than during the upward phase. Asea and Blomberg (1998) have observed that when the economy is strong and default rates are low, banks may expand their business loan portfolios beyond a prudent level creating an adverse selection problem that sets the stage for higher-than-expected default rates that subsequently induce an excessive contraction of bank lending. One hypothesis (advanced by Berger and Udell, 2002) for why this adverse selection problem arises is that the 'institutional memory' of bank loan officers obsolesces over time. During a downward phase, loan officers acquire the skills to recognize poor loan risks, but gradually lose this skill as the recessionary economic environment recedes far into the past. They then begin lowering standards so that loan quality deteriorates and thus setting the stage for high default rates at some future date. It is a view consistent with persistent weakness in the volume of business loans as the economy enters the recovery phase of an economic business cycle.

\section{Concluding Remarks and Policy Recommendations}

In this paper we examine the empirical relationship between business cycles and bank lending in South Africa. Overall evidence suggesting procyclicality of bank lending is uncovered both at macro and micro level. At macro level, bank lending and lending rates have moved in tandem with business cycles. Lending volumes have risen during upturns and fallen during downturns while lending rates have declined during upturns and risen during downturns. In the 1980 s, real borrowing by government was pro-cyclical as fiscal and monetary policies responded to non-economic factors. However, in the 1990s, real borrowing by government was countercyclical to business cycles as would be expected if the role of government was to fine-tune the economy during booms and recessions. At micro level, bank lending to households and firms was generally pro-cyclical. Even the growth of provisioning by banks has been largely pro-cyclical to business cycles. However, exceptions were recorded. New mortgage lending exhibited counter-cyclical behavior before 1993. We attributed this behavior to the 
political and economic climate prevailing then which created uncertainties that made ownership of property a good hedge against economic and political risks. From 1993 onwards when the transition to majority rule became certain, new mortgage lending became pro-cyclical as predicted by theory. With regard to other recorded exceptions, the growth of real credit for investment and of foreign trade finance does not appear to have been related to business cycles. We are happy that real credit for investment and for trade finance behaves in this fashion as they tend to be loans usually unaffected by stages of the business cycle. This falls more in line with the country's economic objective of investment as well as export promotion.

The growth of bills discounted was counter-cyclical during the first four business cycles under consideration and became hardly related to the business cycle thereafter.

Bank lending, as analyzed, is largely consistent with theoretical expectations. Our analysis suggests the importance of the government of South Africa to continue to fine tune the economy during booms and downturns.

\section{Note}

1. According to the Centre for International Business Cycle Research at Columbia University, between 1854 and 1945 the average expansion lasted 29 months and the average contraction 21 months. Since the Second World War, however, expansions have lasted almost twice as long, an average of 50 months, and contractions have shortened to an average of only 11 months.

\section{References}

Altunbas, Y., O. Fazylov and P. Molyneux (2002), 'Evidence on the Bank Lending Channel in Europe', Journal of Banking and Finance, Vol. 26, pp. 2093-110.

Asea, P.K. and S.B. Blomberg (1997), 'Lending Cycles', NBER Working Paper No. w5951.

Asea, P. and S.B. Blomberg (1998), 'Lending Cycles', Journal of Econometrics, Vol. 83, pp. 89-128.

Berger, A.N. (2003), 'The Efficiency Effects of a Single Market for Financial Services in Europe', European Journal of Operational Research, Vol. 150, pp. 466-81.

Berger, A. and G. Udell (1992), 'Some Evidence on the Empirical Significance of Credit Rationing', Journal of Political Economy 100, pp. 1047-77. 
Berger, A. and G. Udell (1994), 'Did Risk-based Capital Allocate Credit and Cause a "Credit Crunch" in the United States?', Journal of Money, Credit and Banking, Vol. 26, pp. 585-628.

Berger, A. and G. Udell (2002), 'The Institutional Memory Hypothesis and the Pro-cyclicality of Bank Lending Behavior', Finance and Economic Discussion Series 2003-2, Board of Governors of the Federal Reserve System (February). http://www.federalreserve.gov/pubs/ feds/2003/200302/200302pap.pdf

Bernanke, B.S. and M. Gertler (1989), 'Agency Costs, Net Worth, and Business Fluctuations', American Economic Review, Vol. 79, No. 1, pp. 14-31.

Bernanke, B., M. Gertler and S. Gilchrist (1996), 'The Financial Accelerator and the Flight to Quality', Review of Economics and Statistics, Vol. 78 (February), pp. 1-15.

Bank for International Settlement (BIS) (2003), 'Credit Risk Transfer', Report by the Committee on the Global Financial system, January.

Bank for International Settlement (BIS) (2004), ‘Annual Report', Basel.

Boyd, J.H., R. Levine and B.D. Smith (2001), 'The Impact of Inflation on Financial Sector Performance', Journal of Monetary Economics, Vol. 47, pp. 221-48.

Diamond, D.W. (1984), 'Financial Intermediation and Delegated Monitoring', Review of Economic Studies, Vol. 51, No. 3, pp. 393-414.

Economist, The (2002), 'Crisis? What Crisis?', 16 May.

Einarsson, T. and Marquis, M. (2001), 'Bank Intermediation over the Business Cycle', Journal of Money, Credit and Banking, Vol. 33, pp. 87699.

Farmer, R.E.A. (1985), 'Implicit Contracts with Asymmetric Information and Bankruptcy: The Effect of Rates on Layoffs', Review of Economic Studies, Vol. 52, No. 3, pp. 427-42.

Farmer, R.E.A. (1988), 'Money and Contracts', Review of Economic Studies, Vol. 55, No. 3, pp. 431-46.

Gavin, M., R. Hausmann, R. Perotti and E. Talvi (1996), 'Managing Fiscal Policy in Latin America and the Caribbean: Volatility, Procyclicality and Limited Creditworthiness', Inter-American Development Bank Working Paper No. 326, Washington, DC.

George, H. (1879), Progress and Poverty, Reprint. New York: Robert Schalkenbach Foundation. 
Gorton, G. and J. Kahn (1993), 'The Design of Bank Loan Contracts, Collateral, and Renegotiation’, NBER Working Paper 4273.

Greenwald, B. and J. Stiglitz (1993), 'Financial Market Imperfections and Business Cycles', Quarterly Journal of Economics, Vol. 108, No. 1, pp. $77-114$.

Haberler, G. (1958), Prosperity and Depression: A Theoretical Analysis of Cyclical Movements (3rd edn), George Allen and Unwin, London.

Hellmann, T.F., K.C. Murdock and J.E. Stiglitz (2000), 'Liberalization, Moral Hazard in Banking, and Prudential Regulation: Are Capital Requirements Enough?', American Economic Review, Vol. 90, pp. 14765.

Kashyap, A.K. and J. Stein (1995), 'The Impact of Monetary Policy on Bank Balance Sheets', Carnegie-Rochester Conference Series on Public Policy, Vol. 42, pp. 151-95.

Kashyap, A., J. Stein and D. Wilcox (1993), 'Monetary Policy and Credit Conditions: Evidence from the Composition of External Finance', American Economic Review, Vol. 83, pp. 78-98.

Keynes, J.M. (1936), The General Theory of Employment, Interest, and Money, Harcourt, Brace, New York.

Kishan, R.P. and T.P. Opiela (2000), 'Bank Size, Bank Capital, and the Bank Lending Channel', Journal of Money, Credit, and Banking, Vol. 32, No. 1, pp. 121-41.

Kiyotaki, N. and J. Moore (1997), 'Credit Cycles', Journal of Political Economy, Vol. 105, No. 2, pp. 211-48.

Laubscher, P. (2002), 'The South African Business Cycle Over the 1990s: What Can We Learn?', Trade and Industry Policy Secretariat, 2002 Annual Forum, Glenburn Lodge, Muldersdrift.

Lown, C. and D. Morgan (2001), 'The Credit Cycle and the Business Cycle: New Findings Using the Survey of Senior Loan Officers', Federal Reserve Bank of New York Working Paper.

Nabarro, R. and Key, T. (2003), 'Performance Measurement and Real Estate Lending Risk', BIS Paper No. 21, pp. 70-90.

Peek, J. and E.S. Rosengren (1995), 'Is Bank Lending Important for the Transmission of monetary Policy?', in J. Peek and E.S. Rosengren (Eds.), Is Bank Lending Important for the Transmission of Monetary Policy?, Federal Reserve Bank of Boston Conference Series, No. 39, June, pp. 47-68. 
Pretorius, W.S., J.C. Venter and P.J. Weideman (1999), 'Business Cycles in South Africa during the Period 1993 to 1997', SARB Quarterly Bulletin, March, pp. 38-42.

Rajan, R.G. (1994), 'Why Bank Credit Policies Fluctuate: A Theory and some Evidence', Quarterly Journal of Economics, Vol. 109, No. 2, pp. 399-441.

Repullo, R. (2004), 'Capital Requirements, Market Power and Risk Taking in Banking', Journal of Financial Intermediation, Vol. 13, No. 2, pp. 15682.

Riksbank (2002), 'Financial Stability Report 2002', Article Two. Available online at www.riksbank.com/upload/Dokument_riksbank/Kat_ publicerat/Artiklar_FS/FinancialStability02_2_artikel2.pdf. Accessed on 1 July 2005.

Schoors, K. and R. Vander Vennet (2003), 'Rules versus Discipline: Capital Adequacy Rules, Monitoring Incentives, and Bank Behavior in Transition Economies', Ghent University Working Paper.

Smit, D.J. and B.E. Van Der Walt (1970), 'Business Cycles in South Africa during the Post-war Period, 1946 to 1968', SARB Quarterly Bulletin, September.

Smit, D.J. and B.E. Van Der Walt (1973), 'Business Cycles in South Africa during the Period 1968 to 1972', SARB Quarterly Bulletin, June.

Smith, B. (1995), 'Sectoral Employment and Cyclical Fluctuations in an Adverse Selection Model', International Economic Review, Vol. 36, No. 2, pp. 261-81.

South African Reserve Bank (several years), Quarterly Bulletin, South African Reserve Bank, Pretoria.

South African Reserve Bank (2005a), '2004 Annual Report of Bank Supervision', Department of Bank Supervision, South African Reserve Bank, June, Pretoria.

South African Reserve Bank (2005b), 'Electronic Database', South African Reserve Bank, Pretoria. Available online at www.reservebank.co.za. Accessed on 31 January 2005.

South African Reserve Bank (2007), Quarterly Bulletin, March, No. 243, South African Reserve Bank, Pretoria.

Sturzenegger, F. and R.L.F. Werneck (2004), 'Fiscal Federalism and Procyclical Spending: The Cases of Argentina and Brazil', available at 
http://200.32.4.58/ fsturzen/version\%20final\%20august.pdf, accessed on 13 May 2008.

Talvi, E. and C.A. Vegh (2000), 'Tax Base Variability and Procyclical Fiscal Policy', NBER Working Paper 7499, January.

Van Der Walt, B.E. (1989), 'Business Cycles in South Africa during the Period 1981 to 1987', SARB Quarterly Bulletin, March.

Van Der Walt, S.J. (1997), 'Bank Credit to the Private Sector', SARB Quarterly Bulletin, June. Available on http://www.reservebank.co.za/internet/ Publication.nsf/LADV/C7DCCD2A6981784B42256B56004C0F98/\$File/ Article0697.pdf, Accessed on 31 March 2005.

Van der Walt, B.E. and W.S. Pretorius (1995), 'Business Cycles in South Africa during the Period 1986 to 1993', SARB Quarterly Bulletin, March.

Venter, J.C. and W.S. Pretorius (2001), 'A Note on the Business Cycle in South Africa during the Period 1997-1999', SARB Quarterly Bulletin, September.

Zarnowitz, V. (1985), 'Recent Work on Business Cycles in Historical Perspective: A Review of Theories and Evidence', Journal of Economic Literature, Vol. 23, No. 2, pp. 523-80.

\section{Appendix}

Table A1: Business cycle phases in South Africa since 1945

\begin{tabular}{lclc}
\hline Upward phase & $\begin{array}{c}\text { Duration } \\
\text { in months }\end{array}$ & \multicolumn{1}{c}{ Downward phase } & $\begin{array}{c}\text { Duration } \\
\text { in months }\end{array}$ \\
\hline Post-war-July 1946 & 7 & August 1946-April 1947 & 9 \\
May 1947-November 1948 & 19 & December 1948-February 1950 & 15 \\
March 1950-December 1951 & 22 & January 1952-March 1953 & 15 \\
April 1953-April 1955 & 25 & May 1955-September 1956 & 17 \\
October 1956-January 1958 & 16 & February 1958-March 1959 & 14 \\
April 1959-April 1960 & 13 & May 1960-August 1961 & 16 \\
September 1961-April 1965 & 44 & May 1965-December 1965 & 8 \\
January 1966-May 1967 & 17 & June 1967-December 1967 & 7 \\
January 1968-December 1970 & 36 & January 1971-August 1972 & 20 \\
September 1972-August 1974 & 24 & September 1974-December 1977 & 40 \\
January 1976-August 1981 & 44 & September 1981-March 1983 & 19 \\
April 1983-June 1984 & 15 & July 1984-March 1986 & 21 \\
April 1986-February 1989 & 35 & March 1989-May 1993 & 51 \\
June 1993-November 1996 & 42 & December 1996-August 1999 & 33 \\
September 1999- & & & 20.4 \\
Overall average & 25.6 & & 44.3 \\
\% period in upswing & 55.7 & \% of period in downturn & \\
\hline
\end{tabular}

Source: SARB (2007). 